\title{
Evaluation of Learning System on Teacher Educational Profession Programs
}

\author{
EPON NINGRUM
}

Fakultas Pendidikan IImu Pengetahuan Sosial, Universitas Pendidikan Indonesia. Jl. Setiabudi No. 229 Bandung email: epon.ningrum@yahoo.com

\begin{abstract}
This research aims at describes the evaluation of learning system on Subject Specific Pedagogy (SSP) workshop at UPI's Teacher Educational Profession (TEP). This research used descriptive method, with variable was a system of learning and indicators of SSP implementation, principle learning workshop, peer teaching, school observation, and Field Experience Program. Number of respondents participated were 187 TEP students and courses manager of 9 TEP for Post SM3T batch 4 (SM3T: The Bachelor Degree Education Program for Remote, Outlying and Disadvantaged Regions). The results show that: (1) the workshop on SSP TEP Post SM3T batch 4 was implemented at the level of universities and courses through eight stages; (2) the principle of learning-oriented processes and products; (3) peer teaching involving all students, supervisors, mentor teachers, and lectures on specific study program; (4) the observation at school and classroom to do classroom action research; and (5) the student has submitted SSP workshop readiness for academic, pedagogical, and teaching materials of FEP.
\end{abstract}

Keywords: Teacher Educational Profession, Learning System, Subject Specific Pedagogy

\section{Introduction}

Education has important and strategic role in preparing the country and nation to have the readiness and ability to participate and compete in open era society. For this reason, the government implements educational services to all citizens by paying attention to the principle of equity and balance in all regions throughout Indonesia. One of the educational service programs for remote areas is the Indonesian Advanced Learning and Education Program. The program is intended for fresh graduates in educational science who have not yet served as teachers and are willing to be assigned in the remote areas for a year. The Bachelor Degree Education Program for Remote, Outlying and Disadvantaged Regions is a program of the Ministry of Education and Culture to improve education quality in remote areas (commonly known as SM3T in Indonesia).

Educational successes are influenced by many factors of both internal and external. Internal factors regarding interests and motivation to participate in educational process. This condition is closely related to public trust in education in guaranteeing the fulfillment of learning or educational needs, while external factors are related to geographical and socio-cultural conditions. Geographical conditions are often obstacles to gain access to education due to the distance, location, or transportation factors. Culturally, women in poor families have limited access to education because they are accustomed to giving in trait and being gentle (Fatimah, 2014)not separated from the dominant role of parents and parents communicate communication quality that increase access to education for girls to get out of poverty. The results showed that poor family communication in coastal areas towards gender equality girls in access to higher education due to the assumption of girls who are always accustomed to budge, be gentle and accepting the leadership and guidance of men makes them always questioned the approval of the male for advancement and opportunity they get. Family communication in coastal areas include openness, empathic attitude, attitudes supportive, positive attitude and the attitude of equality in communication within the family for the sake of gender equality. This

Received: April 10, 2018, Revision: Agustus 01, 2018, Accepted: December 11, 2018

Print ISSN: 0215-8175; Online ISSN: 2303-2499. DOI: http://dx.doi.org/10.29313/mimbar.v34i2.3668.367-377

Accredited B based on the decree No.040/P/2014, valid on February, 18, 2014 until February, 18, 2019. Indexed by DOAJ, Sinta, IPI 
communication requires social and cultural construction of the subject-object understood, dominant-not dominant, superior-imperior and a balanced division of roles between male family members (father, son).

Education is a conscious and planned effort to create learning atmosphere and learning process so that students would actively develop their potentials to have religious spirit, self-control, personality, intelligence, noble character, and skills needed by themselves, society, nation and state (Republik Indonesia, 2003). Furthermore, it is explained that education is carried out with the principles of habituation, civilization, and empowerment. These three principles can be implemented if available educators or teachers are the spearhead of the operational process of education. Educator is a component of education that has an important role of facilitating the potential transformation of students learning into competence. Learning becomes a vehicle for students to gain learning experiences and outcomes (Kemendikbud, 2013a).

At the operational level, learning becomes the heart of the education process, so that the success of learning becomes the terminology for achieving educational goals. Learning is seen as a process and a system (Ningrum, 2009). Learning as a process is carried out based on process standards consisting of planning and implementation of learning (Kemendikbud, 2016a), as well as activities assessment in accordance with assessment standards (Kemendikbud, 2016b). Learning as a system is indicated by learning components that interact functionally to achieve effective and efficient learning. The existence of teachers in learning, both as a process and a system, has a strategic role for ongoing educational interactions.

The teacher is one component of learning that must fulfill formal juridical requirements. Teachers must meet academic qualification standards, educator competency standards, and hold educator certificates (Republik Indonesia, 2005). These three requirements are obtained through continuous academic education and professional profession education. Academic education develops academic competencies, namely mastering science in the fields of study, education, and learning to achieve academic qualifications (bachelor and diploma). Meanwhile, Program of Teacher Educational Profession (TEP) emphasizes professional competence through the application of academic competencies in the practice of teacher professions to obtain educator certificates. Teacher Educational Profession is a means for the formation and development of professional procedure to achieve professional competence or qualifications (Kemendikbud, 2010).

Teacher is a professional educator with the main duty to educate, teaching, giving guidance, directing, training, scoring, and evaluating students in education from early age, elementary school, and high school (Republik Indonesia, 2005). Teacher is a professional educator who has to fulfill the three requirements when performing their profession, which are: academic qualification, the standard of teacher competencies, and the educator certificate (Kemendikbud, 2007). Competence is defined as set of knowledge, skills, and attitude that teachers need to have, comprehend, and are capable of in doing their professional works. Teachers of learning agents should have four competences of pedagogical, personality, social, and professional. It is important to learn about learning process to increase the quality of learning. Besides, teacher should have the capability to actualize their role as manager of class in order to realize the conducive learning (Ningrum, 2014).

The TEP program is organized to prepare bachelors from educational science and non-educational science who have talent and interest in becoming teachers to master all teacher competencies based on national education standards, so that they can obtain professional educator certificates in early childhood education, basic education, and higher education (Kemendikbud, 2013b). Furthermore, as it is mentioned, the specific purpose of TEP program is to produce prospective teachers who have the competence in planning, implementing, and assessing learning; to follow up the results of assessment, to conduct guidance, to train students, and to conduct research on its study field. The TEP Program for Post-SM3T is intended for bachelors in educational science who have participated in the SM3T program, then included to the TEP Program by Ministry of Research, Technology, and Higher Education.

The curriculum of TEP program has characteristics in aspects of structure or pattern, content, and learning system. The curriculum structure of TEP program presents two choices namely block and non-block 
systems which carried out in one year or two semesters with a learning course about 36-38 credits (Kemenristekdikti, 2016). The learning system consists of two stages: the workshop of Subject Specific Pedagogy (SSP) and the Field Experience Program (FEP). FEP is an implemented teaching method in real classroom which settings in partner schools with minimal B accreditation. Based on that, it is considered important to conduct the learning system evaluation of the TEP Program for Post-SM3T batch 4, 2016.

According to Beast, evaluation is concerned with a more immediate application, seeking a particular educational product, process, or program in defining and agreedupon objectives or value (Ningrum, 2009). Evaluation activities carried out to determine the effectiveness and efficiency of a program and the impact occurred after the program was implemented. A good evaluation is one that can provide useful data and information for the improvement of a program, as a form of follow-up on the results of the evaluation (Arikunto \& Cepi, 2010). Educational program evaluation activities are performed to determine the level of suitability between planning and implementation and getting information for following-up, so that the program achieves its effectiveness.

This study deals with learning system evaluation of the TEP Program for Post-SM3T batch 4 which held at Universitas Pendidikan Indonesia (UPI). The study focused on the workshop learning system of Subject Specific Pedagogy (SSP) which includes: the implementation of SSP workshops, principles of learning, teaching, school observation, and readiness to implement FEP.

\section{Research Method}

This research uses descriptive methods to describe the learning system variables of SSP-TEP workshop with four indicators: (1) the implementation of SSP workshops; (2) principles of learning; (3) teaching, partner school observation; and (4) FEP readiness. Respondents were 187 TEP students and 9 TEP Course Managers for Post SM3T batch 4 in UPI. The subject of TEP Program in UPI are: (1) Mathematics Education; (2) Physics Education; (3) Biology Education; (4) Building engineering education; (5) PKN (Civic) Education; (6) Geography Education; (7) PGSD (Elementary Teacher) Education; (8) English Language Education; and (9) Economic
Education. The research instruments use questionnaires, observation sheets, interview guidelines, and documentation study. Data analysis uses descriptive statistics with interpretations on each aspect of analysis.

\section{Workshop of Subject Specific Pedagogy (SSP)}

The research on the learning systems evaluation of Subject Specific Pedagogy (SSP) in the TEP Program Post-SM3T batch 4 used standard criteria (Permendiknas No. 87 of 2013). This is in accordance with Ibrahim's opinion that evaluation activities have three characteristics, namely: (1) there are criteria used as the basis for determining values; (2) always involves a comparison between criteria and reality; and (3) this comparison is relative (Ningrum, 2016). This evaluation study was to find out to what extent the objectives of TEP Program for Post-SM3T batch 4 could be achieved. The achievement was the match between the learning system of the SSP in TEP Post-SM3T workshop with the standard criteria on five aspects, i.e. (1) the implementation of SSP workshop; (2) the principle of learning; (3) peer teaching; (4) observing partner schools, and (5) readiness to join FEP.

SSP-TEP Course Activities Post-SM3T batch 4 was held by collaboration between the management of university level and study program level. At university level, the course was conducted through the $1^{\text {st }}$ plenary activity, namely academic orientation activities to equip students with the fundamentals of TEP Program and boarding life. The evaluation results indicate that there was an elaboration and addition of the subject matter of TEP standard. Additional material includes: (1) public lectures; (2) strengthening national identity and character; student guidelines and services, as well as student code of ethics; (3) the policies and procedure of central and regional education; (4) academic guidelines and academic administrative services; and (5) orientation of TEP program location. Meanwhile, the courses conducted by the management of study program are: (1) ethics and aesthetics of professional teachers; (2) teacher performance assessment; (3) continuous professional development; and (4) group motivation and dynamics.

\section{Result and Discussion}

The courses of SSP-TEP Post-SM3T at study program management level were done 
through seven stages of activities, namely (1) $2^{\text {nd }}$ plenary activity, (2) pretest, (3) workshop, (4) $3^{\text {rd }}$ plenary activity, (5) individual/group task, (6) observation to partner schools, and (7) peer teaching. The seven activities were divided into two activities, namely the initial activities and the activities of SSP workshop. The initial activity was a preparation to conduct the implementation of SSP-TEP PostSM3T. Based on questionnaire results, the initial SSP workshop activities at the level of study program managers are presented in Table 1.

Table 1

The Involvement of Students in Initial Workshop Activities of the SSP-TEP SM3T

\begin{tabular}{|c|c|c|c|}
\hline \multirow[t]{2}{*}{ No. } & \multirow[t]{2}{*}{ Activities } & \multicolumn{2}{|c|}{$\begin{array}{l}\text { Amount } \\
\text { of TEP } \\
\text { Students }\end{array}$} \\
\hline & & & $\%$ \\
\hline 1 & $\begin{array}{l}\text { Introducing the study } \\
\text { program }\end{array}$ & 187 & 100 \\
\hline 2 & Scheduling of SSP workshop & 172 & 91,98 \\
\hline 3 & $\begin{array}{l}\text { The place of SSP workshop } \\
\text { activities }\end{array}$ & 171 & 91,44 \\
\hline 4 & Meeting with mentor lecturers & 160 & 85,56 \\
\hline 5 & Meeting with mentor teachers & 78 & 41,71 \\
\hline 6 & $\begin{array}{l}\text { Information about Partner } \\
\text { School for FEP }\end{array}$ & 92 & 49,20 \\
\hline 7 & \begin{tabular}{|l|}
$\begin{array}{l}\text { TEP Curriculum for each } \\
\text { subject }\end{array}$ \\
\end{tabular} & 169 & 90,37 \\
\hline 8 & $\begin{array}{l}\text { Technical meeting for SSP } \\
\text { workshop }\end{array}$ & 181 & 96,79 \\
\hline 9 & $\begin{array}{l}\text { The Purposes of SSP } \\
\text { workshop }\end{array}$ & 180 & 96,26 \\
\hline 10 & The Stages of SSP workshop & 183 & 97,86 \\
\hline 11 & $\begin{array}{l}\text { The learning principal of TEP } \\
\text { Course }\end{array}$ & 159 & 85,03 \\
\hline 12 & $\begin{array}{l}\text { The achievement of SSP } \\
\text { workshop }\end{array}$ & 154 & 82,35 \\
\hline 13 & $\begin{array}{l}\text { The lesson plan example } \\
\text { exposure }\end{array}$ & 144 & 77,01 \\
\hline 14 & $\begin{array}{l}\text { The learning media example } \\
\text { exposure }\end{array}$ & 141 & 75,40 \\
\hline 15 & $\begin{array}{l}\text { The learning material } \\
\text { example exposure }\end{array}$ & 154 & 82,35 \\
\hline 16 & $\begin{array}{l}\text { The assessment tool example } \\
\text { exposure }\end{array}$ & 154 & 82,35 \\
\hline 17 & Pretest & 150 & 80,21 \\
\hline 18 & Pretest discussion & 84 & 44,92 \\
\hline 19 & Additional course and review & 146 & 78,07 \\
\hline 20 & Specialization course & 151 & 80,75 \\
\hline
\end{tabular}

Source: Research Data, 2016

Based on Table 1, it shows that in general, the substance of the SSP workshop's initial activities consisted of three aspects, namely: technical implementation, guiding mechanism, and strengthening learning material. Technical discussion of the implementation of SSP-TEP Post SM3T batch 4 workshop involved students, mentor teachers, mentor lecturers, and lecturers of certain subjects. This activity is an effort for students to get deeper understanding of given course by mentor teachers, mentor lecturers, and lecturers in certain subject, so that the student will gain more motivation and participation in each stage of SSP workshop. Learning environment can foster motivation and encourage participation in learning activities (Dewi, 2009). Stabilization of learning material is based on results analysis of pretest guided by lecturers in the field of study. The principle of constructivist learning is prioritizing prior knowledge and conceptual-change processes to gain new knowledge through the process of adjusting new concepts based on existing frameworks (Suparno, 2001).

Based on questionnaire results and observations, the implementation of the SSPTEP workshop Post-SM3T batch 4 at the study program level is presented in Table 2.

Table 2

The Involvement of Students in Workshop Activities of SSP-TEP SM3T

\begin{tabular}{|c|c|c|c|}
\hline No & Activities & $\begin{array}{l}\text { Am } \\
\text { of T } \\
\text { Stu } \\
\text { F }\end{array}$ & $\begin{array}{l}\text { ount } \\
\text { EP } \\
\text { dents } \\
\%\end{array}$ \\
\hline 1 & $\begin{array}{l}\text { School Curriculum Analysis } \\
\text { (Subject) }\end{array}$ & 152 & 81,28 \\
\hline 2 & $\begin{array}{l}\text { Analysis of Basic Competencies } \\
\text { and Determination of Materials/ } \\
\text { Themes }\end{array}$ & 185 & 98,93 \\
\hline 3 & Discussion of Learning Systems & 168 & 89,84 \\
\hline 4 & $\begin{array}{l}\text { Discussion of Learning } \\
\text { Assessment }\end{array}$ & 170 & 90,91 \\
\hline 5 & $\begin{array}{l}\text { Discussion with the mentor } \\
\text { lecturer }\end{array}$ & 154 & 82,35 \\
\hline 6 & $\begin{array}{l}\text { Discussion with the mentor } \\
\text { teacher }\end{array}$ & 104 & 55,61 \\
\hline 7 & Lesson Plan Workshop & 187 & 100 \\
\hline 8 & Learning Media Workshop & 187 & 100 \\
\hline 9 & Teaching Materials Workshop & 187 & 100 \\
\hline 10 & Assessment Tool Workshop & 187 & 100 \\
\hline 11 & $\begin{array}{l}\text { Supervised by mentor lecturer } \\
\text { and teacher }\end{array}$ & 127 & 67,91 \\
\hline 12 & Group discussion & 187 & 100 \\
\hline 13 & Presentation of workshop results & 182 & 97,33 \\
\hline 14 & $\begin{array}{l}\text { Reflections from the mentor } \\
\text { lecturer }\end{array}$ & 145 & 77,54 \\
\hline 15 & $\begin{array}{l}\text { Reflection from the mentor } \\
\text { teacher }\end{array}$ & 125 & 66,84 \\
\hline 16 & $\begin{array}{l}\text { Reflections from the lecturers in } \\
\text { certain study field }\end{array}$ & 165 & 88,24 \\
\hline 17 & $\begin{array}{l}\text { Advice and comments from } \\
\text { other students }\end{array}$ & 187 & 100 \\
\hline
\end{tabular}




\begin{tabular}{|c|l|c|c|}
\hline 18 & Improving teaching materials & 180 & 96,26 \\
\hline 19 & $\begin{array}{l}\text { Approval from the mentor } \\
\text { lecturer for peer teaching/ } \\
\text { microteaching }\end{array}$ & 146 & 78,07 \\
\hline 20 & $\begin{array}{l}\text { Approval from the mentor } \\
\text { teacher for peer teaching/ } \\
\text { microteaching }\end{array}$ & 78 & 41,71 \\
\hline
\end{tabular}

Source: Research Data, 2016

Based on Table 2, it shows that the implementation of SSP workshop in the study program has elaborated on TEP standard, namely seven SSP workshop activities. In its implementation, the seven steps are operationally translated into 20 steps of SSP-TEP Post SM3T batch 4 activities. The characteristic of SSP-TEP workshop is learning by doing activities. Activities at each stage are accompanied by three facilitators, namely two lecturers (lecturer in the field of study and mentor lecturer), and a mentor teacher. The existence of mentor teacher and mentor lecturer who act as facilitators in learning activities can foster motivation to learn and achieve effective and efficient learning activities (DePorter, 2007).

\section{The Principal of Learning}

Based on data from observations and documentation studies, the SSP-TEP PostSM3T batch 4 workshop activity implemented learning principles of: (1) the activity of students; (2) higher order thinking; (3) the effect of accompaniment; (4) utilization of information technology; (5) contextual learning; (6) the use of multi strategy and various learning resources; (7) learning by doing; and (8) feedback mechanism. This is in accordance with the learning principles of
TEP standard. The eight learning principles are the actualization of habituation process in learning activities. In addition, the principle of empowerment is realized by the process of developing high-level thinking skills for students to gain knowledge and experience about learning which oriented towards developing analytical-critical thinking skills. Implementation of learning principle in SSP workshop activities is visualized in Figure 1.

The implementation of SSP-TEP workshop Post-SM3T batch 4 generally begins with $2^{\text {nd }}$ plenary activity, which is the discussions between students and mentor lecturer, mentor teacher, and lecturer in certain field study. The theme of discussion is about learning material, learning methods, and learning media. In the discussion activities, students are motivated to share their knowledge and experiences. This creates conducive learning environment for the actualization of critical thinking skills, analytical thinking, and creative thinking. Discussions can develop mutual learning, mutual respect, and exchange of knowledge as important elements in learning and habituation processes for the realization of learning communities (Ningrum, 2009).

SSP-TEP workshop Post-SM3T reflects independent learning activities as indicators of learning principles implementation of student activity, contextual learning, learning by doing, and the use of learning resources. Learning principle is a vehicle for the acquisition of learning experiences to develop the ability to use learning resources. The ability to use multi strategies and learning resources can improve student competence (John, Teh-Cheong Poh Ai, Yencken, Sykes, \& Treagust, 2014)., while the principle of contextual learning can help

\begin{tabular}{|l|l|l|}
\hline The Principal of Learning & & Workshop SSP \\
Learning with Doing & & 1. $2^{\text {nd }}$ Pleno Activity \\
Participation of Students & 2. Discussion \\
High Order Thinking & 3. Independent work \\
Companion Impact & 4. $3^{\text {rd Pleno Activity }}$ \\
Mechanism of Feedback & 5. Independent/group work \\
Use of Information Technology & 6. School observation \\
Contextual Learning & 7. Microteaching \\
Multi strategy and Various Learning & 8. Peer teaching \\
Resources & \\
& \\
\end{tabular}

Figure 1: Implementation of Learning Principles in the Workshop of SSP-TEP Post SM3T batch 4. 
students recognize macro environment to help transfer of learning (DePorter \& Hernacki, 2007).

The principle of learning while acting is actualized in the activities of making learning devices, so that students get learning experiences and learning outcomes in the form of learning plan documents. The ability to design learning including the implementation of learning plans, learning media, preparation of teaching materials and student worksheets, the development of assessment instruments is one of the TEP graduate competencies (Kemenristekdikti, 2016). Students not only gain knowledge, but also practical abilities that useful to strengthening their professional competencies.

In $3^{\text {rd }}$ plenary activity, the presentation of SSP workshop results was carried out by all students and was attended by lecturer of field study, mentor lecturer, and mentor teacher. The activity actualizes the principle of feedback mechanism learning, namely getting corrections for revisions and followingup to continuous improvement. These activities encourage behavioral changes as learning outcomes, namely changes in knowledge, attitudes, and abilities to deal with FEP activities. These activities facilitate the occurrence of behavioral changes as a result of learning, namely the possession of knowledge, attitude and skill readiness so that they have the confidence to implement FEP. They have self-efficacy, i.e. belief or trust in their ability to carry out and complete tasks and overcome obstacles to achieve goals (Pudjiastuti, 2012).

\section{Peer Teaching/ Microteaching}

Peer-holding activities are held in $3^{\text {rd }}$ plenary activity after students present the results of SSP workshop, improve the teaching material, and get approval from the mentor lecturer and mentor teacher. Based on data from observations and questionnaires, there are 22 aspects relating to peer teaching/ microteaching activities as presented in Table 3.

Table 3

The Activity of Microteaching/Peer Teaching TEP Post-SM3T batch 4

\begin{tabular}{|l|l|c|c|}
\hline \multirow{2}{*}{ No } & Activities & \multicolumn{2}{|c|}{ Amount of } \\
& & TEP Students \\
& & F & $\%$ \\
\hline 1 & Scheduling Peer Teaching & 146 & 78,07 \\
\hline
\end{tabular}

\begin{tabular}{|l|l|l|l|}
\hline 2 & $\begin{array}{l}\text { Place determination for Peer } \\
\text { Teaching }\end{array}$ & 187 & 100 \\
\hline 3 & $\begin{array}{l}\text { Mentor lecturer and teacher } \\
\text { exposure }\end{array}$ & 174 & 93,05 \\
\hline 4 & $\begin{array}{l}\text { Place determination for } \\
\text { Reflection }\end{array}$ & 145 & 77,54 \\
\hline 5 & Scheduling for Reflection & 162 & 86,63 \\
\hline 6 & $\begin{array}{l}\text { Compilation of Observation } \\
\text { Instrument }\end{array}$ & 176 & 94,12 \\
\hline 7 & $\begin{array}{l}\text { Performance as model } \\
\text { teacher }\end{array}$ & 184 & 98,40 \\
\hline 8 & Performance as observer & 178 & 95,19 \\
\hline 9 & $\begin{array}{l}\text { Assessment by mentor } \\
\text { teacher as model teacher }\end{array}$ & 109 & 58,29 \\
\hline 10 & $\begin{array}{l}\text { Assessment by mentor } \\
\text { lecturer as model teacher }\end{array}$ & 127 & 67,91 \\
\hline 11 & $\begin{array}{l}\text { Every student performs as } \\
\text { model teacher }\end{array}$ & 169 & 90,37 \\
\hline 12 & $\begin{array}{l}\text { Every student performs as } \\
\text { observer }\end{array}$ & 159 & 85,03 \\
\hline 13 & $\begin{array}{l}\text { Direct reflection from mentor } \\
\text { teacher }\end{array}$ & 113 & 60,43 \\
\hline 14 & $\begin{array}{l}\text { Direct reflection from mentor } \\
\text { teacher }\end{array}$ & 143 & 76,47 \\
\hline 15 & $\begin{array}{l}\text { Getting comment and } \\
\text { suggestion from other } \\
\text { students }\end{array}$ & 182 & 97,33 \\
\hline 16 & Reflection on performance & 186 & 99,47 \\
\hline 17 & $\begin{array}{l}\text { Reflection on mastery of } \\
\text { material }\end{array}$ & 187 & $\begin{array}{l}100 \\
\text { class }\end{array}$ \\
\hline 19 & Reflection on learning media & 185 & 98,93 \\
\hline 20 & $\begin{array}{l}\text { Reflection on learning } \\
\text { interaction }\end{array}$ & 183 & 97,86 \\
\hline 21 & $\begin{array}{l}\text { Reflection on learning } \\
\text { method }\end{array}$ & $\begin{array}{l}\text { Important note on all step of } \\
\text { reflection }\end{array}$ \\
\hline
\end{tabular}

Source: Research Data, 2016

Table 3 shows three important aspects in peer teaching activities, namely: room or class, learning activities, and reflection. Teaching room for SSP workshop activities uses venue as their learning classes. Thus, students who become model teachers can carry out mobility activities as one of the basic skills of teaching in aspects of variation (Kusnandar, 2008; Usman, 2005).

Peer teaching is an exercise or simulation to strengthening skills in implementing teaching techniques, so that students will be ready to implement FEP (Ningrum, 2009). The time used in this activity is in accordance with the allocation of number of lesson hours in one meeting. Thus, students as model teachers can carry out full training activities, starting from preliminary, core activities, to closing (Kemendikbud, 2016a). During the learning process, students who become 
model teachers actualize their teaching skills and roles in learning as exercises for successful teaching. Peer teaching is an effort of training to achieve learning effectiveness and efficiency (Ningrum, 2009).

Conceptually, peer teaching and microteaching have two different concepts (Usman, 2005). The purpose of microteaching is to train one of the basic teaching skills. The subject matter is simplified, so that the time needed would not be for the whole learning activities, but only for 10-15 minutes (Asril, 2010). Meanwhile, peer teaching aims to train the ability of prospective teachers to carry out full learning before the colleagues or fellow students. Thus, at the operational level, microteaching activities are first carried out then followed by peer teaching.

Reflection is an important part of peer training because students will know the occurred deficiency and achieved goals in the class. In addition, students will have an attitude towards the abilities they have achieved. Therefore, reflection activities have two benefits: first, benefits for all students in the implementation of teaching because it is done together; second, benefits for individual students as a reflection of material independently for further improvement. Reflection becomes the process of forming knowledge and learning skills as well as attitudes and behaviors as teachers (Asril, 2010).

Microteaching activity is an effort for the construction of teaching skills. Teaching is a process of establishing the teaching profession, while real teaching in the FEP setting is an effort to strengthening professional competence. Teacher's profession is formed through a process of formation and experience to meet the requirements (Hamalik, 2001). Teaching skills and role of teachers in learning process become very important aspects of the creation of learning environment that can foster the motivation and encourage student in learning activities (DePorter \& Hernacki, 2007).

\section{Observation of Partner Schools}

One of the stage activities at SSP-TEP workshop is observation of partner schools. A partner school is selected together with a tutor teacher, which is the school where a teacher tutor teachers. Based on documentation studies and interviews with managers of TEP Post-SM3T batch 4, there are 60 partner schools as the place of observation for the initial FEP activities. Partner schools consisted of elementary schools, junior high schools, and high school/vocational schools with 95 mentor teachers and 63 mentor lecturers. Results of questionnaire data on observation activities in partner schools are presented in Table 4.

\section{Table 4}

\section{Observation Activity in Partner School of TEP Post-SM3T batch 4}

\begin{tabular}{|c|c|c|c|}
\hline \multirow[t]{2}{*}{ No } & \multirow[t]{2}{*}{ Activity } & \multicolumn{2}{|c|}{$\begin{array}{l}\text { Number } \\
\text { of TEP } \\
\text { Students }\end{array}$} \\
\hline & & $\mathrm{F}$ & $\%$ \\
\hline 1 & Period time is 1 to 2 weeks & 180 & 96,26 \\
\hline 2 & Study Program/P2JK Guide & 127 & 67,91 \\
\hline 3 & $\begin{array}{l}\text { Technical Explanation from } \\
\text { Supervisor / Study Program }\end{array}$ & 158 & 84,49 \\
\hline 4 & Introduction to the School & 187 & 100 \\
\hline 5 & $\begin{array}{l}\text { Delivering the Objectives of } \\
\text { Observation }\end{array}$ & 168 & 89,84 \\
\hline 6 & $\begin{array}{l}\text { School Environment } \\
\text { Orientation }\end{array}$ & 140 & 74,87 \\
\hline 7 & Curriculum Orientation & 145 & 77,54 \\
\hline 8 & Order Orientation & 125 & 66,84 \\
\hline 9 & $\begin{array}{l}\text { Orientation of Extracurricular } \\
\text { Activities }\end{array}$ & 120 & 64,17 \\
\hline 10 & Class Learning Observation & 155 & 82,89 \\
\hline 11 & To Record the Class Observer & 173 & 92,51 \\
\hline 12 & Interview with Students & 128 & 68,45 \\
\hline 13 & $\begin{array}{l}\text { To Record the Results of } \\
\text { Interviews with Students }\end{array}$ & 134 & 71,66 \\
\hline 14 & Interview with Teacher & 176 & 94,12 \\
\hline 15 & $\begin{array}{l}\text { To Record the Results of } \\
\text { Interviews with Teachers } \\
\end{array}$ & 170 & 90,91 \\
\hline 16 & Hold Documentation Studies & 102 & 54,55 \\
\hline 17 & $\begin{array}{l}\text { To Records the Documentation } \\
\text { Study Results } \\
\end{array}$ & 98 & 52,41 \\
\hline 18 & $\begin{array}{l}\text { To Take Notes of School } \\
\text { Observation Results }\end{array}$ & 172 & 91,98 \\
\hline 19 & $\begin{array}{l}\text { Identifying the Learning } \\
\text { Problems }\end{array}$ & 180 & 96,26 \\
\hline 20 & $\begin{array}{l}\text { Formulating the Learning } \\
\text { Problems }\end{array}$ & 180 & 96,26 \\
\hline 21 & \begin{tabular}{|l|} 
Finding Solution for \\
Troubleshooting \\
\end{tabular} & 174 & 93,05 \\
\hline 22 & $\begin{array}{l}\text { Discussion of Observation } \\
\text { Results }\end{array}$ & 165 & 88,24 \\
\hline
\end{tabular}

Source: Research Data, 2016

Based on data presented in Table 4, it shows that only one activity was carried out by all students of TEP Post-SM3T batch 4, namely introducing the school. Whereas, the activity of taking notes on the results of documentation study was carried out by some students who made observations in partner schools. Observation activities in partner schools are very important to be carried 
out to get a general picture of situation and conditions of the school. School observation becomes the initial knowledge for students to get to know the learning environment in the process of strengthening professional competence (Kemendikbud, 2010). Thus, at the time of FEP, students have already had the ability to adapt, communicate, and interact with the school community as a process of forming and strengthening the competence of educators.

Based on the results of documentation study, there are two objectives of partner school observation activities. The first one is to get to know the school culture and observe the learning process (Kemenristekdikti, 2016). The first objective is to prepare FEP-TEP PostSM3T, so that students have knowledge about the school where FEP-TEP held. Students recognize the academic culture quite well and the academic support activities that take place in partner schools. Students will get a process of strengthening the competence of educators, namely: pedagogical competence, professional competence, social competence, and personality competence (Republik Indonesia, 2005).

The second objective is students get an overview of the learning process that takes place in the classroom, especially related to the field of study. It is important to identify learning problems, especially in educational interaction processes between learning components (Ningrum, 2009) and student learning outcomes. The ability to respond to learning problems and implement actions of solutions is one of the teacher's competencies in pedagogical aspects in carrying out his profession (Kemendikbud, 2007).

In addition, problem identification is done through interviews with students and subject teachers, and also documentation studies. Data which obtained through classroom observations, interviews, and documentation studies are material reflections of learning. The product of this second objective is a class action research design that will be carried out during FEP-TEP activities. In essence, classroom action research is specific class which includes learning components to improve the quality of learning (Ningrum, 2014).

Based on acquisition of research data, it shows that important aspects of planning classroom action research have not been fully implemented by all students. Data of taking notes in the results of documentation studies shows the lowest number, which is only implemented by 98 students. Time of conducting orientation activities exceeds the allocated time of 1-2 weeks (Kemenristekdikti, 2016). It shows that school observation activities are not optimal as equipment for students in designing classroom action research.

Teacher competency in conducting research is to improve the quality of learning and solve learning problems through reflection of learning activities. One of teacher's competencies to reflect on learning activities and make learning improvements is to conduct classroom action research (Kusnandar, 2008). Class action research is a systematic study in solving learning problems through reflective and collaborative actions to improve learning processes and outcomes (Ningrum, 2014).

\section{Readiness of Field Experience Practice (FEP)}

Based on documentation study, Universitas Pendidikan Indonesia uses block system for the curriculum of TEP Program Post-SM3T batch 4 in 2016, i.e. first semester is for SSP workshop activity and second semester is for implementing Field Experience Program (FEP). Student readiness to participate in FEP is characterized by indicators of academic readiness, readiness to carry out learning, and completeness of learning device documents. The three readiness indicators for implementing FEPTEP are obtained through the SSP-TEP SM3T workshop in first semester. Based on data from documentation study and interviews with TEP Post-SM3T batch 4, the SSP-TEP workshop products are presented in table 5 .

Table 5

Product of SSP TEP SM3T Post-SM3T batch 4 Workshop

\begin{tabular}{|c|l|c|c|c|}
\hline \multirow{2}{*}{ No } & \multicolumn{1}{|c|}{ Product } & Form & \multicolumn{2}{|c|}{ Quantity } \\
& & F & \% \\
\hline 1 & Learning Material & $\begin{array}{l}\text { Softfile/ } \\
\text { Hardfile }\end{array}$ & 187 & 100 \\
\hline 2 & Lesson Plan & $\begin{array}{l}\text { Softfile/ } \\
\text { Hardfile }\end{array}$ & 187 & 100 \\
\hline 3 & $\begin{array}{l}\text { Research } \\
\text { Instrument }\end{array}$ & $\begin{array}{l}\text { Softfile/ } \\
\text { Hardfile }\end{array}$ & 187 & 100 \\
\hline 4 & Learning Media & $\begin{array}{l}\text { Softfile/ } \\
\text { Hardfile }\end{array}$ & 187 & 100 \\
\hline 5 & $\begin{array}{l}\text { Classroom Action } \\
\text { Research Design }\end{array}$ & $\begin{array}{l}\text { Softfile/ } \\
\text { Hardfile }\end{array}$ & 187 & 100 \\
\hline
\end{tabular}

Source: Research Data, 2016 
Data presented in table 5 shows that all students of TEP Post-SM3T batch 4 made and produced five teaching material documents during SSP workshop process. This shows that students have readiness to carry out FEP activities in accordance with TEP standards. The availability of teaching material documents is developed according to the characteristics of partner schools and meets process standards. In addition, students have experience and ability to create standardized learning material through a process of theoretical-academic guidance and empirical practice.

Student readiness is the result of learning process that applies learning principles oriented to high-level thinking and active participation in habituation, so that they have competence in designing and preparing learning devices in accordance with process standards (Kemendikbud, 2016a). In fact, class action research design documents do not include learning tools, but rather become mandatory documents set as a result of SSP workshop. This shows that students get a knowledge, experience, and ability to become professional teachers who addressing and overcoming problems in learning. In addition, they are also developing the power of creativity in criticizing learning process to improve the quality of learning, both in process and results.

In general, students' readiness to carry out FEP-TEP activities includes five aspects, namely: academic preparedness, ready to practice (performance), ready to learn the documents, and ready to develop professionalism through class action research design. In addition, mental readiness can be expressed by knowledge of partner schools in order to adapt and interact with their academic environment, so that they can become part of the school community. Thus, students have confidence in their ability to carry out FEP-TEP activities. Students' readiness to implement FEP shows that they have psychological independence namely emotional independence, action independence, and value independence (Wahyudin, 2012).

Academic readiness is expressed by the results of pretest and stabilization of material in accordance with learning needs of TEP PostSM3T batch 4 students. Those indicate that TEP students have been prepared and fulfilled substantial competencies in the field of study or subjects in accordance with the Standards of Content. The readiness implements learning in real situation (real teaching). Readiness to carry out learning is shown by the process during SSP workshop activities which include, discussion, self-employment/ group work, and peer training; while the readiness of learning device document is the result of product assessment in the form of a portfolio. Each student must submit a portfolio consisting of: lesson plans, learning media, assessment instruments, learning materials, and class action research designs.

The ability to plan and manage learning programs is the competence of teachers to develop student potential, both in academic and thinking skills (Bruyere, Wesson, \& Teel, 2012; Kusnandar, 2008; Lie, 2005). Based on the results of interviews with program managers of TEP, there are differences and product similarities in SSP workshop activities results. The differences in SSP results are the development of syllabus, learning method, syntax of learning model, learning skills, learning media, study result from scientific journals, student worksheets, and analysis of learning materials. Whereas, the similarity results are lesson plan, teaching materials, learning media, learning instruments, and proposals of classroom action research.

Based on documentation study, the learning tools of SSP workshop activity products have inequality in structure or format. However, in principle, it can fulfill the substance and components of each learning device. The SSP workshop activity demonstrates its effectiveness in the ability to plan and readily implement learning. Students of TEP Program have pedagogical and professional competence as a whole to become professional teacher candidates (Kemendikbud, 2010).

\section{Conclusion}

The workshop on Subject Specific Pedagogy (SSP) Teacher Educational Profession (TEP) Program for Post SM3T batch 4 was carried out through eight stages of activities held at the management of university level and study program level. The activity at university level is $1^{\text {st }}$ plenary activity to equip students with TEP fundamental. The SSP workshop activities are carried out at management of study program. The learning principle implements eight learning principles oriented towards active involvement and development of high order thinking skills. The learning process is 
an effort to facilitate learning experiences, learning outcomes, and learning products for students. Peer teaching activities provide a full learning experience about implementing learning that is in accordance with process standards and assessment standards. Peer teaching is a means for actualizing basic skills of teaching and implementing teacher's role in learning. School observation is an activity to recognize school culture, to communicate, to interact with school community, and to reflect on learning for classroom action research designs. Readiness to implement Field Experience Program (FEP) in partner schools is characterized by academic readiness, pedagogical readiness to carry out learning, completeness of learning device documents, and class action research plans.

Based on government policy, the TEP Program requires boarding students and implementing institutions to provide boarding facilities. Thus, the recommendation for further research is evaluation of boarding life in student of TEP Post-SM3T.

\section{Acknowledgment}

On this occasion, the author expressed her gratitude to the Rector of Universitas Pendidikan Indonesia (UPI), Program Managers and students of Teacher Educational Profession (TEP) Post-SM3T in UPI who provided data and information. To the Ministry of Research, Technology, and High Education, the Directorate General of Research and Development Strengthening, the Directorate of Research and Community Service which has provided funding for university superior research in 2016.

\section{References}

Arikunto, S., \& Cepi. (2010). Evaluasi Program Pendidikan Pedoman Teoretis Praktis Bagi Mahasiswa dan Praktisi Pendidikan [Educational Program Evaluation Practical Theoretical Guidelines for Students and Educational Practitioners]. Jakarta: Bumi Aksara.

Asril, Z. (2010). Micro Teaching Disertai dengan Pedoman Pengalaman Lapangan [Micro Teaching Accompanied by Field Experience Guidelines]. Jakarta: Rajawali Press.

Bruyere, B. L., Wesson, M., \& Teel, T. (2012). Incorporating Environmental Education into an Urban After-School Program in New York City. Education International
Journal of Environmental \& Science Education, 7 (2), 327-341. Retrieved from http://openjournals.libs.uga.edu/index. php/jheoe/article/view/506\%0Ahttp:// files.eric.ed.gov/fulltext/ED539960.pdf

DePorter, B., (2007). Quantum Teaching: Orchestrating Student Success. Boston: Ally and Bacon.

DePorter, B., \& Hernacki, M. (2007). Quantum Learning: Membiasakan Belajar Nyaman dan Menyenangkan [Quantum Learning: Familiarizing Learning with Comfort and Fun]. Bandung: Kaifa.

Dewi, R. (2009). Studi Kasus Pengetahuan dan Kepedulian terhadap Lingkungan Hidup [Case Study of Knowledge and Concern for the Environment]. Jurnal Damianus, 8(2), 112-114.

Fatimah, J. M. (2014). Komunikasi Keluarga Meningkatkan Akses Pendidikan bagi Kesetaraan Anak Perempuan dalam Lingkaran Kemiskinan [Family Communication Improves Access to Education for the Equality of Girls in the Circle of Poverty]. MIMBAR, Jurnal Sosial Dan Pembangunan, 30(2), 199-208. https://doi.org/https://doi.org/10.29313/ mimbar.v30i2.753

Hamalik, O. (2001). Proses Belajar Mengajar [Teaching and Learning Process]. Jakarta: Bumi Aksara.

John, F., Teh-Cheong Poh Ai, I., Yencken, D., Sykes, H., \& Treagust, D. (2014). Youth Environmental Attitudes in Australia and Brunei: Implication for Education. The Environmentalist, 31(2), 205-216. https://doi.org/https://doi. org/10.1023/A:1016571526997

Kemendikbud. (2007). Permendiknas No. 16 Tahun 2007 tentang Kualifikasi dan Kompetensi Guru [Minister of National Education Regulation No. 16 of 2007 concerning Teacher Qualifications and Competencies]. Jakarta.

Kemendikbud. (2010). Re-Desain Pendidikan Profesional Guru [Re-Design of Teacher Professional Education]. Bandung: Universitas Pendidikan Indonesia.

Kemendikbud. (2013a). Permendikbud No. 64 tahun 2013 Tentang Standar Isi [Regulation of the Minister of Education and Culture No. 64 of 2013 concerning Content Standards].

Kemendikbud. (2013b). Permendikbud No. 87 tahun 2013 tentang Program Pendidikan Profesi Guru [Regulation of the Minister of Education and Culture No. 87 of 2013 concerning the Teacher Professional Education Program]. 
Kemendikbud. (2016a). Permendikbud No. 22 Tahun 2016 tentang Standar Proses [Regulation of the Minister of Education and Culture No. 22 of 2016 concerning Process Standards].

Kemendikbud. (2016b). Permendikbud No. 23 Tahun 2016 Tentang Standar Penilaian [Regulation of the Minister of Education and Culture No. 23 of 2016 concerning Assessment Standards].

Kemenristekdikti. (2016). Panduan PPG 2016 [TEP 2016 Guide]. Jakarta.

Kusnandar. (2008). Guru Profesional: Implementasi Kurikulum Tingkat Satuan Pendidikan (KTSP) dan Sukses dalam Sertifikasi Guru [Professional Teachers: Implementation of Education Unit Level Curriculum and Success in Teacher Certification]. Jakarta: Rajawali Press.

Lie, A. (2005). Cooperative Learning: Mempraktikan Cooperative Learning di Ruang-Ruang Kelas [Cooperative Learning: Practicing Cooperative Learning in Classrooms]. Jakarta: Gramedia Widiasarana Indonesia.

Ningrum, E. (2009). Kompetensi Profesional Guru dalam Konteks Strategi Pembelajaran [Teacher Professional Competence in the Context of Learning Strategies]. Bandung: Buana Nusantara.

Ningrum, E. (2014). Penelitian Tindakan Kelas Panduan Praktis dan Contoh [Classroom Action Research Practical Guidelines and Examples]. Yogyakarta: Ombak.

Ningrum, E. (2016). Capaian Pembelajaran Workshop Subject Spesific Pedagogic (SSP) Pendidikan Profesi Guru di Universitas Pendidikan Indonesia [Achievement of
Learning Workshop Workshop on Specific Pedagogic (SSP) Teacher Professional Education at the Universitas Pendidikan . In Proseding Seminar Internasional UPSIUPI 2016. Bandung.

Pudjiastuti, E. (2012). Hubungan "Self Efficacy" dengan Perilaku Mencontek Mahasiswa Psikologi [The Relationship of "Self Efficacy" with Cheating Behavior of Psychology Students]. MIMBAR, Jurnal Sosial Dan Pembangunan, 28(1), 103-112. https://doi.org/https://doi. org/10.29313/mimbar.v28i1.344

Republik Indonesia. (2003). Undang-undang Nomor 20 Tahun 2003 Tentang Sistem Pendidikan Nasional [Law Number 20 of 2003 concerning the National Education System]. Jakarta.

Republik Indonesia. (2005). Undang-undang Nomor 14 Tahun 2005 Tentang Guru dan Dosen [Law Number 14 of 2005 concerning Teachers and Lecturers]. Jakarta.

Suparno, P. (2001). Filsafat Konstruktivisme dalam Pendidikan [Philosophy of Constructivism in Education]. Yogyakarta: Kanisius.

Usman, M. U. (2005). Menjadi Guru Profesional [Become a Professional Teacher]. Bandung: Remaja Rosdakarya. Wahyudin, U. (2012). Pelatihan Kewirausahaan Berlatar Ekokultural untuk Pemberdayaan Masyarakat Miskin Pedesaan [Ecocultural Background Entrepreneurship Training for Empowering Rural Poor Communities]. MIMBAR, Jurnal Sosial Dan Pembangunan, 28(1), 55-64. https://doi.org/https://doi. org/10.29313/mimbar.v28i1.339. 